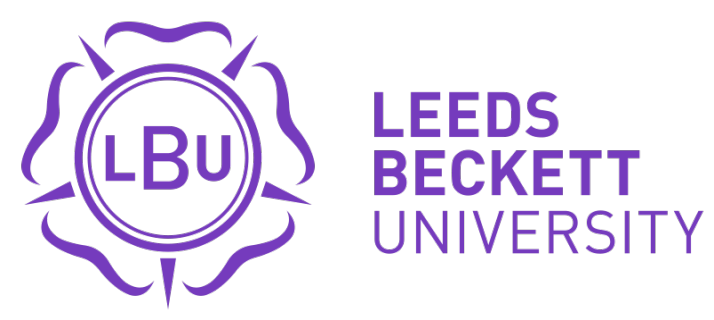

Citation:

Nasir, MA and Duc Huynh, TL and Vo, XV (2020) Exchange rate pass-through \& management of inflation expectations in a small open inflation targeting economy. International Review of Economics \& Finance. ISSN 1059-0560 DOI: https://doi.org/10.1016/j.iref.2020.04.010

Link to Leeds Beckett Repository record:

https://eprints.leedsbeckett.ac.uk/id/eprint/6789/

Document Version:

Article (Accepted Version)

The aim of the Leeds Beckett Repository is to provide open access to our research, as required by funder policies and permitted by publishers and copyright law.

The Leeds Beckett repository holds a wide range of publications, each of which has been checked for copyright and the relevant embargo period has been applied by the Research Services team.

We operate on a standard take-down policy. If you are the author or publisher of an output and you would like it removed from the repository, please contact us and we will investigate on a case-by-case basis.

Each thesis in the repository has been cleared where necessary by the author for third party copyright. If you would like a thesis to be removed from the repository or believe there is an issue with copyright, please contact us on openaccess@leedsbeckett.ac.uk and we will investigate on a case-by-case basis. 


\title{
Exchange Rate Pass-Through \& Management of Inflation Expectations in a Small Open Inflation Targeting Economy
}

\author{
Muhammad Ali Nasir, Toan Luu Duc Huynh, Xuan Vinh Vo \\ Leeds Beckett University, United Kingdom \\ University of Economics Ho Chi Minh City, Vietnam \\ WHU - Otto Beisheim School of Management, Germany
}

\begin{abstract}
In the context of inflation targeting, this study analyses the exchange rate pass-through (ERPT) to inflation expectations in a small open inflation targeting economy. We also augment the inflation expectations function with GDP, inflation, unemployment, fiscal stance, oil prices and money supply. Drawing on the data from May 1999 to Dec 2018 on the Czech Republic, which was the first developing country to adopt inflation targeting, our key results suggest that ERPT has significant implications for inflation expectations. Inflation expectations are also strongly influenced by actual inflation and past inflation expectations suggesting evidence of adaptive expectations. Economic growth, labour market outlook, money supply, oil price shocks and fiscal stance also showed a considerable impact on inflation expectations, though results varied in the short and long run. Our study contributes to the debate on ERPT and inflation targeting by reflecting on the inflation expectations channel.
\end{abstract}

Key Words: Exchange Rate Pass-Through, Inflation Targeting, Oil Shocks, Monetary Policy, Money supply, Inflation, Inflation Expectations, Nonlinear ARDL, NKPC.

JEL Classification: E24, E31, E43, E52, E58, E61, E62, D84. 


\section{Introduction}

Exchange rate dynamics have crucial implications for the internal as well as the external balance of any economy and the significance of exchange rate dynamics is known at least as far back as Hume (1742) and his notion of price-specie flow mechanism. Depreciation implies a reduction in ability to buy what was previously bought per unit of currency, and hence, in relative terms, it is typically inferred that an inflationary "exchange-rate pass-through" should occur resulting in an increase in the prices of goods and services. However, there has been considerable debate regarding the transmission mechanism and channels of this putative exchange rate pass-through (ERPT) to the economy and particularly inflation. As Forbes put it "we have surprisingly poor understating of exactly how exchange rate movements affect inflation (2016, p.3). An important and potentially moderating factor which fuelled the debate on ERPT is the adoption of inflation targeting (I.T. hereafter). On this aspect, some studies, for instance, Goldfajn and Muinhos (2003) on Brazil, argued that the ERPT might have declined due to I.T. Similarly, Schmidt-Hebbel and Werner (2002), Eichengreen (2002) and Mishkin and Savastano (2001) also suggested that the adoption of I.T. and an associated increase in credibility might have led to diminishing ERPT, keeping the inflation expectations anchored in the face of depreciation. More recently, Junior (2017) supported the notion of a decline in ERPT because of I.T., but also cautioned that it should be not be inferred that the ERPT has become "non-existent". On the contrary, recent empirical evidence on the ERPT and I.T has strongly refuted this line of reasoning (Nasir and Simpson, 2018; Forbes et al. 2017; 2015 and Forbes, 2016) and has shown that, in fact, ERPT has increased in inflation-targeting countries (Nasir and Vo, 2018).

It is important to note, that the primary motive for the adoption of I.T is not to diminish ERPT per se, but to achieve price stability, which is the core objective of monetary authorities. In the pursuit of this objective, a number of central banks have chosen to adopt the strategy of explicit I.T. In its essence, explicit I.T involves estimation and then the public announcement of an objective and quantifiable rate of inflation as the "Target" (Jahan, 2017)1. The target acts as a "nominal anchor" and according to its

\footnotetext{
${ }^{1}$ The optimal targeted rate of inflation is debatable, the notion of having a positive target tracks its root in the argument that some inflation is good and acts to grease the wheel of the economy (Contrast, Tobin 1972, Groshen and Schweitzer 1999, Atkeson and Kehoe, 2004; and Forder, 2014).
} 
most vocal proponents, for instance, Bernanke (2003), the I.T possesses the novel features of both "rules" and "discretion" for this reason it can be rightly called "constrained discretion". Pioneered by New Zealand, the idea of I.T has been widely debated and there are arguments across the spectrum. Proponents have emphasized that I.T. comes with many benefits, including simplicity, transparency, flexibility, accountability, time-consistency etc. (see Nasir et al 2020 for detailed discussion). Among all these benefits described by proponents, an important aspect of strategy is the influence of I.T. on expectations. On this aspect, Williams (2014) argued that explicit, as well as implicit inflation targeting, is helpful in "anchoring expectations and achieving price stability".

Despite overwhelming support it garners, proponents of I.T have acknowledged that it is not a panacea and success depends on the manner of implementation (Bernanke, 200, Mishkin, 2000). Nonetheless, some studies show that there is not always decisive evidence regarding the role of inflation targeting in achieving price stability (Alpanda and Honig, 2014; Angeriz and Arestis, 2008). Since the Global Financial Crisis (GFC) 2008 I.T. has been criticised and even declared "dead" (Frankel, 2012). However, Williams (2014) argues that although in the Post-GFC era, I.T has been successful in bringing price stability and anchoring inflation expectations, there are contemporary challenges because of new monetary policy issues, notably a zero lower bound (ZLB) on interest rates in the context of other problems such as financial stability.

Given the arising issues, the assertion that I.T. has been successful in achieving price stability requires empirical testing, particularly its implications for the inflation expectations. One important aspect that requires attention is the ability of inflation targeting authorities to deliver on the promise to keep inflation expectations well anchored. In fact, the whole notion of I.T. is encapsulated in the idea that through transparency, accountability and commitment to price stability, inflation expectations are anchored (Bernanke, 2001 and 2003; Morgan, 2009). As a consequence of anchoring the inflation expectations of households and firms via the credibility of I.T., it is supposed to have price stability. In this context, it is important to consider the implications of the ERPT for inflation, especially since (to

\footnotetext{
${ }^{2}$ A precise numerical target (rule) for inflation and discretion in the response and policy action.
} 
reiterate) some scholars hold this to be diminished due to the adoption of I.T. Yet, an important channel or moderating factor between exchange rate and the inflation nexus is inflation expectations. Intuitively, if I.T. influences the ERPT, one would anticipate its influence will extend through the expectations channels, since the very purpose of I.T according to its proponents (Bernanke, 2001 and 2003, Mishkin, 2000) is the management of expectations. However, despite the debate on ERPT regarding inflation and the role of I.T in moderating the inflation-exchange nexus, this issue of expectation channels is underappreciated and unexplored.

Theoretical and empirical evidence suggests that in addition to the exchange rate, the determinants of actual inflation are aggregate demand, the outlook of the labour market, supply and cost (e.g. oil) shocks, fiscal policy stance, money supply and past behaviour of inflation, and inflation expectations. It is reasonable to suggest that inflation expectations are themselves influenced by the determinants of inflation. The relationship between inflation expectations and inflation has profound significance and there is substantial theoretical and empirical support for this nexus (see Friedman (1968) and Phelps (1967) or lately Marfatia (2018) and Nasir et al (2020). In this regard, it is supposed that I.T. plays a crucial role in anchoring and mooring inflation expectations, on the basis that pursuit of I.T. increases credibility, accountability and transparency (Morgan, 2009). This being so, I.T. becomes a "Game of managing inflation expectation" not merely the management of inflation. This aspect of I.T. is prima facie evident in the literature; it is the most frequent argument used by proponents of anchoring inflation expectations through I.T. (See Bernanke et al (2001) and Williams (2014). Concomitantly, this raises the question regarding ERPT to inflation expectations: how do inflation expectations respond? To answer this question, we analyse the implication of shocks to inflation expectations in a small and open economy; we select the Czech Republic, which was also the first developing economy to adopt explicit inflation targeting. As an empirical framework of analysis and to draw some inferences and conclusions, we employ a Nonlinear Autoregressive Distributed Lag (N-ARDL) framework. Contingent on the obtainability of data on inflation expectations, we chose monthly observations from May 1997 to Dec 2018. In addition to the exchange rate shock, we include inflation, oil price, money supply, unemployment, output growth and fiscal stance as determinants of inflation expectations. Based on a 
comprehensive empirical estimation exercise, our key findings suggest that the ERPT has significant implications for inflation expectations. Inflation expectations are strongly influenced by actual inflation and past inflation expectations, suggesting evidence of adaptive expectations. Economic growth, labour market outlook, money supply, oil price shocks, and fiscal stance also show considerable impact on inflation expectations, though in our findings results varied in the short and long-run. Our study contributes to the debate on ERPT and inflation targeting through its focus on the inflation expectations channel. It also contributes to debate on I.T. and the notion of keeping inflation anchored in the face of exchange rate shocks. Specifically, we reflect on the role of the expectations channel in the context of debate regarding ERPT under an inflation targeting regime.

The rest of the paper proceeds as follows: in $\S 2$, we revisit the existing evidence on the subject, $\S 3$ sets out a Nonlinear-ARDL framework as a means of analysing the nexus between inflation expectation and its explanatory factors including ERPT. $§ 4$ presents the results and a critical discussion, which leads to conclusions and policy implications in $§ 5$.

\subsection{Inflation Targeting \& ERPT}

An explicit Inflation Targeting (I.T.) regime was first adopted by the Reserve Bank of New Zealand in the early 1990s ${ }^{3}$, followed by Canada (1991), UK (1992) and Sweden and Australia (1993) ${ }^{4}$. In 1997, the Czech Republic was the first Central and East European (CEE) country (and developing country) to adopt the I.T. Although two of the biggest players in central banking i.e. the Fed and ECB were not among earlier adopters of I.T., there was considerable support for opting for explicit I.T and the idea was entertained by various scholars and practitioners (see, Artis and Kontolemis, 1998; Bernanke et al, 2001; and Bernanke, 2003). A number of studies focusing on developing economies also argued in favour of I.T (e.g. Minella et al, 2003; Lee, 2011; Lanzafame, 2016; Balima et al, 2017). In this regard, the most vocal proponents were Bernanke et al (2001). Drawing on empirical evidence they argued strongly that countries which have adopted I.T have experienced lower inflation and lower inflation expectations. Obstfeld (2014) notes that an I.T. framework that deliver a moderate and stable rate of

\footnotetext{
${ }^{3}$ See Reserve Bank of New Zealand Act 1989, available at http://www.legislation.govt.nz/act/public/1989/0157/latest/DLM199364.html for details.

${ }^{4}$ Adoption of I.T continued and on average each year at least one central bank opted for it.
} 
inflation tend to achieve a well-anchored inflation target. The question then follows: what would be the implications of ERPT to inflation expectations under I.T.? Perhaps, as Roger (2010) argued, one of the elements of I.T is a forward-looking assessment of inflation (expectations). Although, Roger's argument was with reference to the targeting authority i.e. the central bank, if placed in conjunction with Bernanke et al (2001) and Obstfeld's (2014) reasoning this also involves forward-looking assessment of inflation by household and firms. Concomitantly, if I.T. diminishes the ERPT to inflation, is it reasonable to assume that this will be reflected in the ERPT to inflation expectations? It is this we intend to empirically establish.

As noted in the introduction, since the GFC, the strategy of I.T has been criticised. Williams (2014) has argued that if we gauge the success of I.T. on the bases of price stability, then it has delivered on its promise, but challenges are posed by both ZLB and the potential for financial instability. In the case of the Czech Republic, the interest rate came close to the ZLB in November 2012, when the Czech National Bank (CNB) reduced its policy rate to $0.05 \%$. This raises the question of the ERPT to inflation and also inflation expectations.

The global inflation outlook has been muted in the Post-GFC era, even in the presence of a prolonged low-interest-rate regime (Haldane, 2015; Nasir, 2017). This could be associated with a number of factors, for instance, unassertive demand and supply pressures, stagnation and low commodity prices. One might ask: how much can we associate this global inflation situation with I.T. and has the ERPT to inflation expectation been influenced by the strategy of I.T.? Moreover, is the global inflation situation as consequence of the strategy of I.T., which has kept inflation expectations anchored or is this a "silver lining" emergent from a deflationary regime and economic outlook? Contextualising these aspects, the subject study focuses on the ERPT to inflation expectations in an I.T. regime.

\subsection{Determinants of Inflation Expectations}

Factors that define the dynamics of actual inflation are logically perceived to influence the expectations of inflation. In broad terms these are demand and supply shocks. In terms of demand shocks, the increase in aggregate demand and an adverse supply shock should cause upward inflation pressures. 
Nonetheless, policy variables and specifically, the policy rate may also influence inflation and inflation expectations. However, policy is a response to inflation and its expectations and given that monetary policy is in proximity to ZLB in a number of countries, including the Czech Republic, there seems little room for manoeuvre ${ }^{5}$. This study is focused on the factors which are traditionally held accountable for inflation and inflation expectations dynamics rather than the effects of policy. The literature on the determinants of inflation is overwhelming. However, the literature on the determinants of inflation expectations is sparse. Given that the nexus between inflation and inflation expectations is extremely strong it is reasonable to argue that what determines inflation should also influence the expectations of inflation (Armantier et al 2016). These determinants include past inflation and aggregate demand pressure (Gali and Gertler, 1999), though the results may vary among countries. For instance, contrasting the US, Euro Area, and the UK, Canova et al (2007) report that in the US demand shocks are most influential on inflation, whereas in the Euro Zone supply shocks were. Interestingly, in the UK demand shocks, supply shocks, as well as monetary policy, had a significant impact. On a broader note, a number of studies focusing on supply and demand shocks as determinants of inflation reported mixed results (for instance, contrast, Boschia and Girardi, 2007; Norkute, 2015; and Lagoa, 2017). Similarly, evidence on developing countries also suggests mixed results (e.g. contrast, Mohanty and Klau, 2001; Unsal and Osorio, 2013; and Mohanty and John, 2015). Regarding inflation expectations Nasir et al $(2020 ; 2020$ b) report significant but contrasting evidence of cost (oil) shocks on inflation expectations the UK, New Zealand, Norway, Sweden and Denmark. Contrasting evidence on the nexus between inflation, inflation expectations, and their determinants, provides a rationale for further exploration.

The role of expectations in determining the behaviour of actual inflation was emphasised by Friedman (1968) and Phelps (1967). Later studies, for instance, Mehra and Herrington (2008) on the US, report that past inflation as well as expected inflation, demand (unemployment) and supply (oil price) shocks influence inflation and inflation expectations. Likewise, a study by Ueda (2010) comparing the response of inflation expectations in the US and Japan to price shocks showed that the effects of exogenous prices

\footnotetext{
${ }^{5}$ Unconventional measures of Asset Purchase Programmes or Q. Es at ZLB are exceptions, see, Haldane, (2015) and Nasir (2017).
} 
on inflation and inflation expectations in the US are not only larger than Japan but also long-lasting and shocks to expectations have self-fulfilling effects on inflation. In contrast, a study by Fuhrer (2011) on the US reported that a short-run relationship prevails between inflation expectations and actual inflation. However, analysing the data on the Euro Area and the UK, Lagoa (2017) and Marfatia (2018) report a strong nexus. In the case of the UK economy, Posen (2011) claims that accounting for inflation expectations (as well anchored) is crucial to understanding and forecasting inflation ${ }^{6}$.

Fiscal policy stance and potential inflationary consequences are contentious. In their seminal paper, Sargent and Wallace (1981) argue that fiscal policy has significant implications for inflation. However, the empirical evidence is mixed and inconclusive (for instance, contrast, Fischer et al, 2002; Catao and Terrones, 2005; and Lin and Chu, 2013). Sargent and Wallace (1986) declare that fiscal policy stance plays a critical role in inflation expectations. Fiscal policy also has implications for successful I.T. (Mikek, 2004). Minea and Tapsoba (2014) argue that fiscal discipline is perceived as a precondition for successful inflation targeting, hence adoption of I.T. can facilitate fiscal discipline. Drawing on Brazilian data Minella et al (2003) and Cerisola and Gelos (2009) argue that inflation expectations are strongly influenced by fiscal policy stance, while past inflation does not affect inflation expectations. They argue further that inflation expectations have remained anchored since the adoption of I.T., even in periods of high uncertainty. Similar to an earlier study by Corbo et al (2001) and contrary to Gali and Gertler (1999), they could not find evidence of inertia in the inflation process. In this study, we investigate this phenomenon of anchoring in the light of ERPT. On the aspect of inertia or persistence in inflation expectations, Yigit (2010) reports a significant reduction post I.T. Given the existence of contrasting evidence, we will consider fiscal stance as well as past behaviour of inflation and inflation expectations in determining the dynamics of inflation expectations in the Czech case.

Friedman (1970), famously stated that "inflation is always and everywhere a monetary phenomenon", and many studies have reported on the impact of the money supply on inflation. For example, among

\footnotetext{
${ }^{6}$ The assertions by Posen (2011) are required to be tested against the empirical evidence, as one may also argue that if the inflation expectation had been strongly anchored then the recent exchange rate shocks in the UK would not have caused the surge in inflation and the weak performance of the Bank of England's forecast (Broadbent, 2017; Nasir, 2017b; Haldane, 2017 and Nasir and Simpson, 2018 ).
} 
recent studies, Lu et al (2017) reports that inflation is positively affected by expansion in the money supply. Su et al (2016), however, find mixed and contrasting results among different periods of analyses. While drawing on data from OECD countries, Hung and Thompson (2016) show that inflation has little to do with money supply dynamics. As regards inflation expectations, an extensive literature search indicates there is little extant evidence that we can refer to here. Whilst acknowledging the contrasting evidence regarding the money supply and inflation, in this study, we consider money supply as a determinant of inflation expectations.

As a final point, the nexus between exchange rate dynamics and inflation can bring crucial challenges to a monetary authority in its endeavour to achieve its targets (Fraga et al 2003). In this regard, some scholars, for instance, Goldfajn and Muinhos (2003) focus on Brazil, and argue that the ERPT might have declined due to I.T. A few studies which focus on the period preceding the GFC argue that the ERPT might have diminished due to the adoption of an explicit I.T. strategy (Eichengreen (2002) Mishkin and Savastano (2001) and Schmidt-Hebbel and Werner (2002). However, there is not much empirical support for this and we suggest that the nexus between ERPT to inflation expectations is underappreciated and underexplored. In a later study, Junior (2017) supports the argument regarding decline of ERPT since the adoption of I.T. in emerging markets, but also caution that it should not be inferred that the ERPT has become non-existent. Recent evidence on the ERPT and I.T. strongly refutes the argument on decline of the former (Nasir and Simpson, 2018, Forbes et al. 2017; Forbes, 2016; Forbes et al, 2015Nasir et al 2020). It shown in fact that it has increased in I.T. countries (Nasir and VO, 2018). Considering the fact that monetary policy in the Czech Republic has been close to the ZLB, a reasonable question to ask is: have inflation expectations remain anchored in the face of shocks from the exchange rate as well as other determinants? Perhaps, the very idea of I.T. is embedded in the notion of anchoring and taming inflation expectations, through credibility, accountability, and transparency. In the next section, we will elaborate on our empirical framework, used to address these issues.

\subsection{Methodology}

We employ an N-ARDL approach to estimate and analyse the association between inflation expectations and underlying variables of interest, namely the real exchange rate, output growth, labour 
market, cost or supply (oil price) shocks, money supply, and fiscal deficit. To start with, we specify it in the form of an open economy NKPC: ${ }^{7}$

$$
\begin{gathered}
\pi_{t}=\beta_{\pi} \pi_{t-i}+\beta_{E \pi} E \pi_{t+i}+\beta_{R E X}(R E X)_{t-i}+\beta_{O G} O G_{t-i}+\beta_{L M S} L M S_{t-i}+\beta_{\text {Fiscal }} \text { Fiscal }_{t-i} \\
+\beta_{O i l} \text { Oil } l_{t-i}+\beta_{M S} M S_{t-i}+e_{t}
\end{gathered}
$$

Where inflation $\left(\pi_{t}\right)$ is determined by its past values i.e. an element of persistence $\left(\pi_{t-i}\right)$, its expectations $(E \pi)$, real exchange rate $(R E X)$. output growth $(O G)$, labour market outlook which can be gauge through the spare capacity or labour market slack $(L M S)$, fiscal policy stance, supply or cost shocks (Oil) shocks and dynamics of the Money Supply (MS). Considering the fact these factors are theoretically perceived and often empirical proved to be the determinants of inflation, the expectations of inflation are also influenced by these factors and their dynamics. Hence,

$$
\begin{aligned}
E \pi_{t}=\beta_{\pi} \pi_{t-i} & +\beta_{E \pi} E \pi_{t+i}+\beta_{R E X}(R E X)_{t-i}+\beta_{O G} O G_{t-i}+\beta_{L M S} L M S_{t-i}+\beta_{\text {Fiscal } \text { Fiscal }_{t-i}} \\
& +\beta_{O i l} O i l_{t-i}+\beta_{M S} M S_{t-i}+e_{t}
\end{aligned}
$$

The novelty of the employed N-ARDL approach is that it takes into account the asymmetries and nonlinearities in the relationship between inflation expectations, the real exchange rate shock and other determinants. As we are interested in investigating these asymmetries and nonlinearities in the context of inflation targeting, N-ARDL is the logically appropriate framework of analysis. The N-ARDL cointegration approach is based on the seminal work by Shin et al (2011) which found its roots in the contributions by Pesaran and Shin (1999) and Pesaran et al. (2001). To start with, we can specify the Eq. $(1 \& 2)$ in the following long-run model of inflation as well as its expectations:

$$
\begin{gathered}
\pi_{t}=a_{0}+a_{1} R E X_{t}^{+}+a_{2} R E X_{t}^{-}+a_{3} E \pi_{t}+a_{4} O G_{t}+a_{5} L M S_{t}+a_{6} \text { Fiscal }_{t}+a_{7} \mathrm{Oil}_{t}+ \\
\quad a_{8} M S_{t}+e_{t} \\
E \pi_{t}=a_{0}+a_{1} R E X_{t}^{+}+a_{2} R E X_{t}^{-}+a_{3} \pi_{t}+a_{4} O G_{t}+a_{5} L M S_{t}+a_{6} \text { Fiscal }_{t}+a_{7} \text { Oil }_{t}+ \\
a_{8} M S_{t}+e_{t}
\end{gathered}
$$

Where $\pi_{t}$ is inflation and $E \pi_{t}$ are inflation expectations and their determinants are as specified in equation ( $1 \& 2), a=\left(a_{0}-a_{8}\right)$ is a co-integrating vector of long-run parameters. In Eq. $(3 \& 4)$ the

\footnotetext{
${ }^{7}$ For arising issues of method see (see Morgan and Patomaki 2017).
} 
$E X_{t}^{+}$and $E X_{t}^{-}$are partial sums of positive and negative changes in the real effective exchange rate, it can be specified as;-

$$
R E X_{t}^{+}=\sum_{i=1}^{t} \Delta R E X_{i}^{+}=\sum_{i=1}^{t} \max \left(\Delta R E X_{i}, 0\right)
$$

and

$$
R E X_{t}^{-}=\sum_{i=1}^{t} \Delta R E X_{i}^{-}=\sum_{i=1}^{t} \min \left(\Delta R E X_{i}, 0\right)
$$

In the light of formulation presented above (Eq. $3 \& 4$ ), the relationship between the real exchange rate shocks $(R E X)$ and inflation expectations $\left(E \pi_{t}\right)$ is expected to be negative $\left(a_{1}\right)$. However, $a_{2}$ accounts for the nexus between REX and inflation expectations while there are reductions in REX or depreciation. As the exchange rate and inflation, as well as inflation expectations, are expected to show the opposite direction of movement, estimates of $a_{2}$ can be expected to yield negative signs. It can also be posited that the decrease in the exchange rate will lead to a higher increase in the inflation expectations than the increase in the exchange rate which may lead to a decrease in the inflation expectations. In simple words, the negative shocks (depreciation) could have larger effect as compared to the positive (appreciation) shocks i.e. $a_{2}>a_{1}$. This implies downward price or exchange rate pass-through rigidity which could be manifested in the inflation expectations. Hence, an asymmetric exchange rate passthrough can be expected in the long run. The Eq.3 and Eq. 4 can be framed into a Nonlinear Autoregressive Distributed Lag Model (NARDL) setting as follows ${ }^{8}$ :

$$
\begin{aligned}
\Delta \pi_{t}=a+\beta_{1} \pi_{t-1} & +\beta_{2} R E X_{t-1}^{+}+\beta_{3} R E X_{t-1}^{-}+\beta_{4} E \pi_{t-1}+\beta_{5} O G_{t-1}+\beta_{6} L M S_{t-1} \\
& +\beta_{7} \text { Fiscal }_{t-1}+\beta_{8} O i l_{t-1}+\beta_{9} M S_{t-1}+\sum_{i=1}^{c} \emptyset_{i} \Delta \pi_{t-i}+\sum_{i=0}^{v}\left(\theta_{i}^{+} \Delta R E X_{t-i}^{+}\right. \\
& \left.+\theta_{i}^{-} \Delta R E X_{t-i}^{-}\right)+\sum_{i=0}^{s} \gamma_{i} \Delta O G_{t-i}+\sum_{i=0}^{v} \delta_{i} \Delta L M S_{t-i}+\sum_{i=0}^{w} \Omega_{i} \Delta \text { Fiscal }_{t-i} \\
& +\sum_{i=0}^{x} \varphi_{i} \Delta E \pi_{t-i}+\sum_{i=0}^{z} \delta_{i} \Delta O i l_{t-i}+\sum_{i=0}^{m} \psi_{i} \Delta M S_{t-i}+e_{t}
\end{aligned}
$$

and

\footnotetext{
${ }^{8}$ For details, see Shin et al. (2011), Pesaran and Shin (1999) and Pesaran et al. (2001).
} 


$$
\begin{aligned}
\Delta E \pi_{t}=a+\beta_{1} E & \pi_{t-1}+\beta_{2} R E X_{t-1}^{+}+\beta_{3} R E X_{t-1}^{-}+\beta_{4} \pi_{t-1}+\beta_{5} O G_{t-1}+\beta_{6} L M S_{t-1} \\
& +\beta_{7} \text { Fiscal }_{t-1}+\beta_{8} O i l_{t-1}+\beta_{9} M S_{t-1}+\sum_{i=1}^{q} \emptyset_{i} \Delta E \pi_{t-i}+\sum_{i=0}^{w}\left(\theta_{i}^{+} \Delta R E X_{t-i}^{+}\right. \\
& \left.+\theta_{i}^{-} \Delta R E X_{t-i}^{-}\right)+\sum_{i=0}^{s} \gamma_{i} \Delta O G_{t-i}+\sum_{i=0}^{v} \delta_{i} \Delta L M S_{t-i} \sum_{i=0}^{w} \Omega_{i} \Delta \text { Fiscal }_{t-i} \\
& +\sum_{i=0}^{x} \varphi_{i} \Delta \pi_{t-i}+\sum_{i=0}^{z} \delta_{i} \Delta O \text { Oil }_{t-i}+\sum_{i=0}^{m} \psi_{i} \Delta M S_{t-i} e_{t}
\end{aligned}
$$

Where we have defined all the variables earlier, $p, \mathrm{q}, \mathrm{s}, \mathrm{v}, \mathrm{w}, \mathrm{x}, z, m$ are lag orders and $a_{1}=-\beta_{2} / \beta_{1}$ $a_{2}=-\beta_{3} / \beta_{1}$ the long-run coefficients of association between $R E X$ dynamics and inflation (Eq. 7) inflation expectations (Eq.8). In Eq. 7, the $\sum_{i=0}^{q} \theta_{i}^{+}$captures the short-run impacts of REX appreciation on inflation, while $\sum_{i=0}^{q} \theta_{i}^{-}$captures short-run impacts of depreciation on inflation. On the other hand, in Eq. $8 \sum_{i=0}^{q} \theta_{i}^{+}$measures the short-run impacts of appreciation on inflation expectations whereas $\sum_{i=0}^{q} \theta_{i}^{-}$measures the short-run impacts depreciation on the inflation expectations. Concomitantly, in this fashion, we account for the asymmetries in both short and long-run relationship between real exchange rate (pass-through) and inflation expectations.

The implementation of the employed N-ARDL framework entails the following steps. To start with, the unit root testing is performed to determine the order of integration of variables. It is worth acknowledging that the subject framework is valid either if the data series is stationary at level i.e. (0) or at first difference i.e. $I(1)^{9}$. Only the $I$ (2) can lead to invalidating the computation of F-statistics to test the cointegration (Ibrahim, 2015). Hence, to ensure that there is no data series with an order of integration $I$ (2) we perform the unit root testing by employing the Augmented Dickey-Fuller (ADF) and Phillips-Perron (PP) approaches. Thereafter we proceed to the estimation of N-ARDL model (Eq.7 \& Eq. 8). After estimation, the bound testing approach is applied to test the presence of cointegration (see Pesaran et al. (2001) and Shin et al. (2011)). The Wald F-test is performed with the null hypothesis, $\beta_{1}=\beta_{2}=\beta_{3}=\beta_{4}=\beta_{5}=\beta_{6}=\beta_{7}=\beta_{8}=\beta_{9}=0$. In the last and final step of the analysis, we would analyse the short and long runt asymmetries in the nexus between inflation expectation and REX.

\footnotetext{
${ }^{9}$ For arising issues see Nasir and Morgan (2018)
} 
The impact of the other independent variables is also discussed. Lastly, the asymmetric cumulative dynamic multiplier is also derived to examine the effects of (1\% $1 \%$ REX i.e. $R E X_{t-1}^{+}$and $R E X_{t-1}^{-}$as:

$$
m_{h}^{+}=\sum_{j=0}^{h} \frac{\partial y_{t+j}}{R E X_{t-1}^{+}}, m_{h}^{-}=\sum_{j=0}^{h} \frac{\partial y_{t+j}}{R E X_{t-1}^{-}}, h=0,1,2 \ldots \ldots \ldots
$$

Noticeably as $h \rightarrow \infty, m_{h}^{+} \rightarrow a_{1}$ and $m_{h}^{-} \rightarrow a_{2}$.

\subsection{Data}

The data was collected on the inflation expectations, inflation, fiscal stance, output growth, labour market, real effective exchange rate, money supply and oil prices (supply/cost shocks). Linear interpolation was performed to match and convert the data to monthly frequencies where necessary. Depending on the availability, the study has a time horizon from May 1999 to December 2018. Details of each proxy for each country is as follows:

Inflation Expectations: For inflation expectations, we used the survey data. Specifically, the data was collected from the Czech National Bank (CNB) which collects it through Business Surveys by including financial market inflation expectations for a three-year horizon.

Inflation: We used the monthly Consumer Price Index, year on year \% change for the Czech Republic as a proxy for inflation. The data was seasonally adjusted and standardized. It is important to note that this is the official measure of inflation used for the inflation targeting by the Czech National Bank.

Supply /Cost (oil) Shocks: To present the cost shocks, data on monthly oil prices are collected (West Texas Intermediate: WTI) from the FRED, Federal Reserve Bank of St. Louis.

Output growth: Data on real GDP growth is employed to represent the output growth outlook of the Czech Republic. The data was year on year growth rate which was standardized and seasonally adjusted. The data was collected from the Czech Statistical Office.

Labour Market: For the labour market outlook and degree of slack, we used the data on the Unemployment Level. The data was collected from the Ministry of Labour and Social Affairs, the Czech Republic. 
Fiscal Stance (Surplus/Deficit): For the fiscal stance, we used the monthly data on budget deficit/surplus, standardized, year on year change. The data was collected from the Czech Ministry of Finance.

Real Exchange Rate: Data on the Real Effective Exchange Rate was used as the proxy for exchange rate the data was obtained from the Bank for International Settlements (BIS) database.

Money supply: For money supply, we collected the monthly data on the M2 which is the broadest measure of money supply available. Data were obtained from the Czech National Bank (CNB).

\section{Analysis, Findings, and Discussion}

\subsection{Stationary tests}

First, we performed the stationary test to verify the existence of unit root in our dataset. The ARDL approach does not strictly require the classification of I(0) or I(1) (Pesaran, Shin, Smith, 2001). We employed the Augmented Dickey-Fuller (ADF) and the Phillips-Perron (PP) test to determine the order of integration. The main reason to test stationary is to assure that all variables are not integrated at $\mathrm{I}(2)$ (Ouattara, 2004) because the F-test is only validated for 'bounds test' in I(0) and I(1). Table 1 summarises the test results:

Table 1. Unit Root Testing at Level

\begin{tabular}{ccc}
\hline Variables & Augmented Dickey-Fuller & Phillips-Perron \\
\hline Inflation Expectation $(E \pi)$ & -2.373 & -2.441 \\
Inflation $(\pi)$ & -2.196 & $-2.756^{*}$ \\
GDP & -1.191 & -2.110 \\
REX & -2.337 & -2.298 \\
Unemployment & $-13.751^{* * *}$ & $-13.931^{* * *}$ \\
Money Supply & $-2.947 * *$ & $-3.353^{* *}$ \\
Oil Price & -2.329 & -2.470 \\
Fiscal (Surplus/Deficit) & $-5.289^{* * *}$ & $-5.301^{* * *}$ \\
\hline
\end{tabular}

Unit Root Testing at first-difference

\begin{tabular}{ccc}
\hline Variables & Augmented Dickey-Fuller & Phillips-Perron \\
\hline Inflation Expectation $(E \pi)$ & $-17.504 * * *$ & $-18.015^{* * *}$ \\
Inflation $(\pi)$ & $-12.776 * * *$ & $-12.940^{* * *}$ \\
GDP & $-3.863 * * *$ & $-4.216^{* * *}$
\end{tabular}




\section{REX}

Unemployment

Money Supply

Oil Price

Fiscal (Surplus/Deficit)
$-13.374 * * *$

$-13.751 * * *$

$$
-2.947 * *
$$$$
-11.349 * * *
$$

$-5.289 * * *$
$-13.323 * * *$

$-13.931 * * *$

$-3.353 * *$

$-11.356^{* * * *}$

$-5.301 * * *$

The symbols *,**, and *** denote the significance at 10\%, 5\%, and $1 \%$ levels, respectively. Note that the 'unemployment', 'money supply' and 'fiscal' is stationary without having first-difference.

There are only three variables which are stationary at the level i.e. $I(0)$, including the unemployment rate, the money supply and fiscal stance. Therefore, we decided to take the first difference operator. As showed in Table 1, all of our variables are found to be stationary at first difference. This implied that we can proceed with the bound testing approach.

\subsection{Bound testing for Nonlinear Co-integration}

The results of Bounds testing for the nonlinear Cointegration are summarised in Table 2:

Table 2. Bounds test for the Nonlinear Cointegration

\begin{tabular}{lllccl}
\hline Dependent variable & F-statistics & K & Lower-Bound (90\%) & Upper-Bound (90\%) & Conclusion \\
\hline Inflation Expectation $(E \pi)$ & 3.071578 & 8 & 1.85 & 2.85 & Cointegration \\
\hline
\end{tabular}

The results of bounding testing showed that the F-statistics were higher than upper bound at a $90 \%$ confidence level. Therefore, the results implied that there exists the long-run relationship between the inflation expectations and its determinants, specified in the Eq. 8. Thus, we can further investigate their association and proceed with the estimation.

\subsection{Inflation Expectations N-ARDL}

The results of the Nonlinear Autoregressive Distributed Lag $(N-A R D L)$ are presented in Table 3.

Table 3. Nonlinear ARDL Inflation Expectation (Ex)

\begin{tabular}{|c|c|c|c|}
\hline \multicolumn{4}{|c|}{ Panel A: Short Run Estimates } \\
\hline Variables & Coefficient & T-statistics & p-values \\
\hline Inflation Expectations $(E \pi)_{t-1}$ & $-0.094036 * * *$ & {$[-2.940418]$} & 0.003 \\
\hline${ }^{\times} R E X_{t}^{+}$ & $-0.280917 * *$ & {$[-1.990737]$} & 0.047 \\
\hline${ }^{\times} R E X_{t}^{-}$ & $-0.257314^{*}$ & {$[-1.692101]$} & 0.092 \\
\hline${ }^{*} \operatorname{Inflation}_{t}(\pi)$ & $0.013211 * *$ & {$[2.531012]$} & 0.012 \\
\hline${ }^{*}$ Oil Price $_{t}$ & 0.035889 & [1.316203] & 0.189 \\
\hline${ }^{\star} G D P_{t}$ & 0.003647 & {$[0.923279]$} & 0.356 \\
\hline${ }^{\times}$Fiscal $_{t}$ & -1.53 & {$[-0.355116]$} & 0.722 \\
\hline${ }^{\circ}$ Money Sumpply ${ }_{t}$ & -0.000351 & {$[-0.589641]$} & 0.556 \\
\hline${\text { Unemployment } \text { rate }_{t-1}}$ & $0.001089 * *$ & {$[2.265241]$} & 0.024 \\
\hline$\Delta$ Inflation Expectations $(E \pi)_{t-1}$ & $-0.167979 * *$ & {$[-2.470080]$} & 0.014 \\
\hline
\end{tabular}




\begin{tabular}{lccc}
$\Delta$ Inflation Expectations $(E \pi)_{t-2}$ & $-0.165423^{* *}$ & {$[-2.477444]$} & 0.014 \\
$\Delta$ Inflation Expectations $(E \pi)_{t-3}$ & $-0.126361^{*}$ & {$[-1.924044]$} & 0.055 \\
$\Delta$ Unemployment rate $_{t}$ & -0.000770 & {$[-0.761243]$} & 0.447 \\
Constant & 0.155845 & {$[1.002696]$} & 0.317 \\
\hline \multicolumn{4}{c}{ Panel B: Long-run Estimates } \\
\hline REX $_{t}^{+}$ & $-2.987320^{* *}$ & {$[-2.148879]$} & 0.0504 \\
RER $_{t}^{-}$ & -2.736321 & {$[-1.632477]$} & 0.1413 \\
Inflation $_{t}$ & $0.140488^{* *}$ & {$[2.490877]$} & 0.0272 \\
Oil Price $_{t}$ & 0.381655 & {$[1.161418]$} & 0.2298 \\
GDP $_{t}$ & 0.038783 & {$[0.787742]$} & 0.4596 \\
Fiscal $_{t}$ & -1.63 & {$[-0.363901]$} & 0.5238 \\
Monemy Supply $_{t}$ & -0.003733 & {$[-0.599885]$} & 0.4845 \\
Unemployment rate $_{t}$ & 0.011581 & {$[1.594534]$} & 0.1095 \\
Constant $^{2}$ & 1.657287 & {$[1.360100]$} & 0.1887 \\
\hline $\mathrm{R}^{2}$ & Panel C: Diagnostic Testing & \\
F-test & 0.976230 & & 0.000 \\
ECT & $749.5326^{* * *}$ & & 0.000 \\
Jarque-Bera (JB) residuals normality test & $-0.094036^{* * *}$ & {$[-5.655427]$} & 0.000 \\
Breusch-Godfrey (BG)LM test & $146.3742^{* * *}$ & & 0.341 \\
Durbin Watson test & 2.1512 & & 0.000 \\
Breusch-Pagan-Godfrey (BPG) test & 1.995797 & & 0.000 \\
White-test & $60.611^{* * *}$ & & 0.814 \\
Ramsey REST Test & $161.298^{* * *}$ & & \\
\hline
\end{tabular}

The symbols $*, * *$, and $* * *$ denote the significance at $10 \%, 5 \%$, and $1 \%$ levels, respectively. ${ }^{*}$ interpreted as $z_{t}=$ $z_{t-1}+\Delta z$. T-statistics of the corresponding coefficients are presented in square brackets. BG LM test with two lags for auto-correlation. Note: Huber-White Hinkley heteroskedasticity-consistent standard errors \& covariance.

The results of N-ARDL model presented in Table 3, contributes to the empirical evidence on the asymmetries and nonlinearities in the relationship between inflation expectations, REX and determinants of inflation expectations in both short and long runs. The short-run estimates (Panel A) suggests a significant negative impact of past-inflation expectations on the prevailing inflation expectations. This implies an inherent correction mechanism of inflation expectations from past judgments as well as the aspect of adaptive inflation expectations. The coefficient of REX in both cases (positive and negative) is negative and significant. To be more precise, the positive $\left(R E X_{t}^{+}\right)$had a negative and significant impact while the negative $\left(R E X_{t}^{-}\right)$also had a negative and but weaker impact. The inflation has shown a positive and significant impact on the inflation expectations suggesting that if the inflation increases it influence the expectations of future inflation. Hence, the regimes of price stability helps to anchors the inflation expectations while the regimes of price instability can influence future inflation expectations, exacerbating future price instability. The oil price shocks, GDP growth, and unemployment have a positive impact in the short run on inflation expectations. The impact of 
unemployment was counterintuitive, however, it might be due to the reason that high unemployment may lead to perceive that the inflation is going to be higher and perceived costs might be higher. The fiscal (surplus/deficit) showed a negative impact implying negative effects of consolidation on inflation expectations while money supply also showed a negative impact.

The long-run estimates (Panel $\mathrm{B}$ ) showed that the positive exchange rate shocks $R E X_{t}^{+}$has a significant negative impact on the inflation expectations at a $5 \%$ level of statistical significance. However, the negative shocks $R E X_{t}^{-}$are found to be negative but insignificant. This indicates that the asymmetry of the ERPT to inflation expectations. In the long run, the effects of current inflation, GDP, oil prices and unemployment rate are found to be positive, while the money supply and fiscal stance are likely to decrease the expected inflation. In addition to the REX, inflation found to be the most significant and hence crucial factor to influence inflation expectations. Lastly, we performed the dialogistic test to examine the robustness of our model and estimates. First of all, the adjusted $\mathrm{R}^{2}$ showed that explanatory variables can explain $97.62 \%$ of the variation in expected inflation. The Error Correction Term (ECT) showed the negative value (-0.094) and significant value (1\% level) which is interpreted as the stability of the model and pace of adjustment. Furthermore, the F-statistics to reject the null hypothesis that all coefficients are zero. The Breusch-Godfrey (BG) LM test and Durbin Watson test suggest that the null of no-auto correlation was not rejected at $1 \%$ level of significance. Therefore, we can conclude that there is no serial correlation for our residual. Therefore, our model is able to use for forecasting. However, we reject the null hypothesis of Jarque-Bera (JB) residuals normality at $1 \%$ significance level. The Breusch-Pagan-Godfrey (BPG) test and White test were performed to check for the heteroscedasticity. We reject the null hypothesis of no heteroscedasticity. However, this error does not lead to unbiased results. The last test is Ramsey-REST test for misspecification. We failed to reject the null hypothesis that there is no misspecification. Concomitantly, it is inferred that our model is correctly specified. 


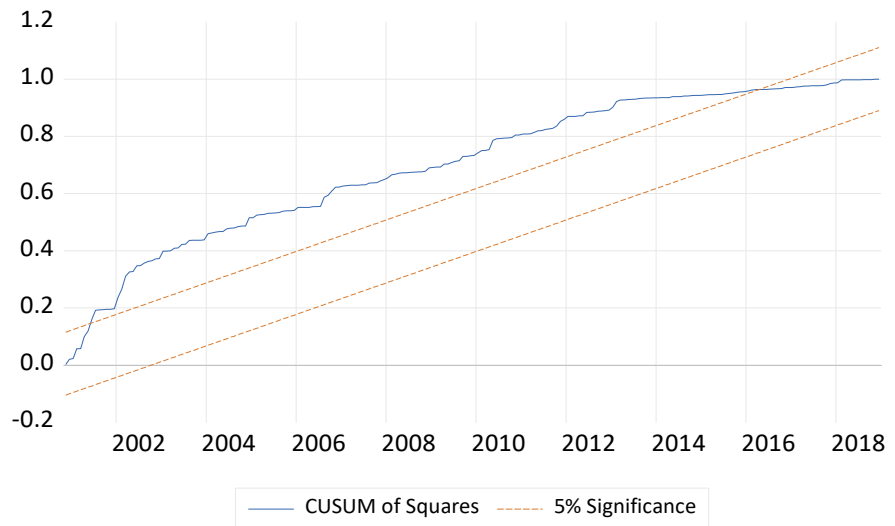

Figure 1. CUSUM and CUSUMSQ Parameter Stability Test for Inflation Expectations

In order to ensure the stability of our model, we performed the parameter stability test. The results for the CUSUM test showed the parameters are stable, for the entire period. The results of CUSUM of Squared test suggested some periods where the parameters crossed the 5\% level, however, they remained in closer to the bound within $10 \%$ level and reverted to the $5 \%$ level suggesting and overall confidence of $90 \%$. We also performed the cumulative multiplier analysis to observe the multiplier impact of real effective exchange rate on inflation expectations. The results are presented in Figure 2:-

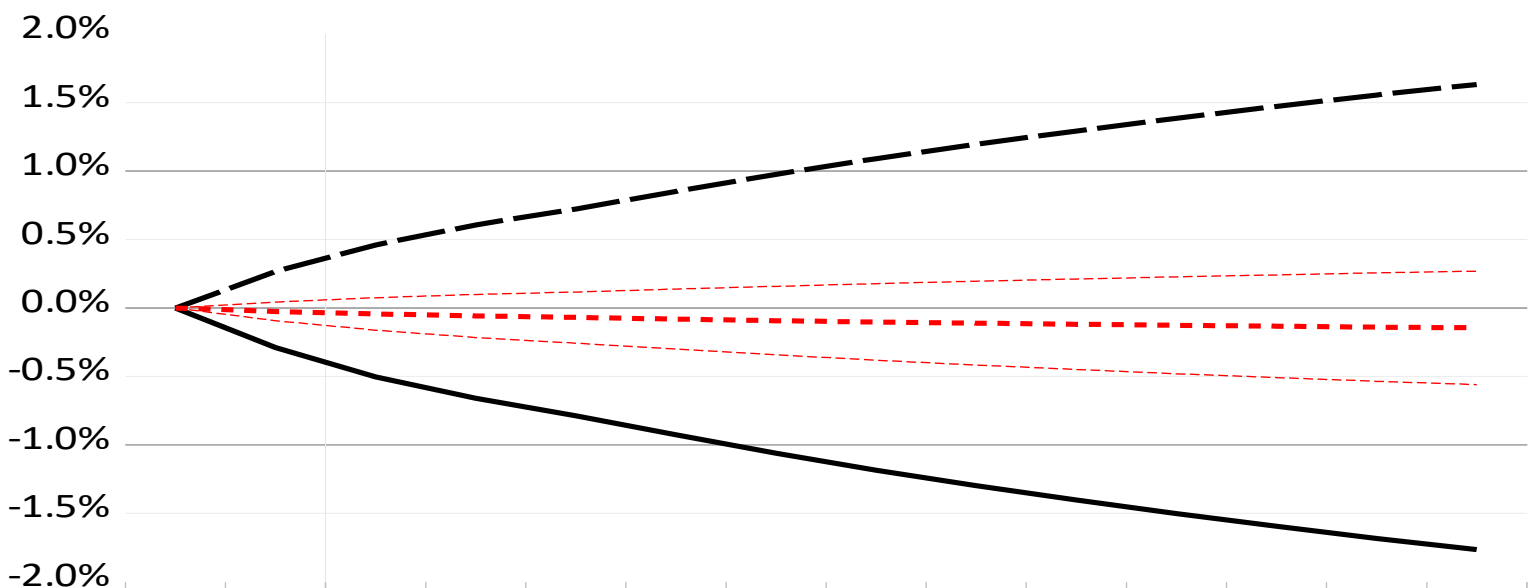

$\longrightarrow$ REX $+1 \%-$ REX $-1 \%$ - $1 \%-$ Difference

Figure 2. NARDL Multiplier of the real effective exchange rate and the response of inflation expectations The results of cumulative multiplier depicted in Fig 3 give an overarching view of the impact of REX on the Czech inflation expectations. An appreciation of Czech koruna or a positive shock to the REX (1\%) leads to negative response from the inflation expectations which persisted for several periods (months). The negative shock to the REX (1\%) or depreciation of Czech koruna leads to an increase in 
the expected inflation over the proceeding periods (months). In nutshell, the ERPT to the inflation expectation is prima facie evident suggesting inflation expectations as an important channel.

\subsection{Robustness check}

In order to further explore and test the robustness of our estimates against heteroscedasticity of the errors and gain a deeper insight into the long-run relationship of underlying variables, we performed the quantile regression. This approach also addresses any potential issue associated with the outlier's effects. If we have $\tau \in(0,1)$, then find $\hat{\beta}_{\tau}$ which satisfies:

$$
\left[\sum_{Y_{i}-X_{i}^{\prime} \beta>0}\left(Y_{i}-X_{i}^{\prime} \hat{\beta}\right) \tau+\sum_{Y_{i}-X_{i}^{\prime} \beta \leq 0}\left(Y_{i}-X_{i}^{\prime} \hat{\beta}\right)(1-\tau)\right] \rightarrow \min
$$

Then, we have the quantile regression for each $\tau \in(0,1)$

$$
Q_{\tau}\left(Y_{i} \mid X_{i}\right)=X_{i}^{\prime} \hat{\beta}_{\tau}+\widehat{U}_{i \tau}
$$

Table 4 presents the estimates obtained from the quantile regression while addressing the potential heteroscedasticity issue.

\begin{tabular}{|c|c|c|c|c|c|}
\hline & q10 & $q 25$ & q50 & q75 & q90 \\
\hline \multirow{2}{*}{ Inflation $(\pi)$} & $0.104 * * *$ & $0.129 * * *$ & $0.132 * * *$ & $0.114 * * *$ & $0.078 * * *$ \\
\hline & [0.017] & {$[0.010]$} & [0.008] & [0.018] & [0.019] \\
\hline \multirow{2}{*}{ GDP } & -0.022 & $-0.038 * * *$ & $-0.030 * * *$ & $-0.067 * *$ & $-0.098 * * *$ \\
\hline & [0.015] & [0.008] & [0.007] & [0.029] & [0.026] \\
\hline \multirow{2}{*}{ REX } & $-4.403 * * *$ & $-4.172 * * *$ & $-4.143 * * *$ & $-5.086 * * *$ & $-5.223 * * *$ \\
\hline & {$[0.271]$} & [0.287] & [0.203] & [0.428] & [0.771] \\
\hline \multirow{2}{*}{ Unemployment } & 0.002 & $0.004 * * *$ & $0.003 * * *$ & -0.001 & $-0.005 * *$ \\
\hline & {$[0.002]$} & {$[0.001]$} & {$[0.001]$} & {$[0.003]$} & {$[0.002]$} \\
\hline \multirow{2}{*}{ Money Supply } & $0.007 * * *$ & $0.006 * * *$ & $0.005 * * *$ & $0.004 * *$ & 0.001 \\
\hline & {$[0.002]$} & {$[0.001]$} & {$[0.001]$} & {$[0.002]$} & {$[0.003]$} \\
\hline \multirow{2}{*}{ Oil Prices } & $0.204 * *$ & $0.155^{* *}$ & $0.124 * *$ & $0.371 * *$ & $0.473 * *$ \\
\hline & {$[0.083]$} & {$[0.062]$} & {$[0.051]$} & {$[0.143]$} & {$[0.197]$} \\
\hline \multirow{2}{*}{ Fiscal } & -1.39 & $-3.00 * * *$ & $-5.14 * * *$ & $-8.41 * * *$ & -3.40 \\
\hline & {$[0.000]$} & {$[0.000]$} & {$[0.000]$} & [0.000] & {$[0.000]$} \\
\hline \multirow{2}{*}{ Constant } & $20.94564 * * *$ & $20.22614 * * *$ & $20.310 * * *$ & $23.89568 * * *$ & $24.52874 * * *$ \\
\hline & [0.939] & [1.103] & [0.836] & [1.565] & [2.767] \\
\hline
\end{tabular}

Table 4. Quantile Regression Inflation Expectation ( $E \pi)$

$(*),(* *),(* * *)$ reflected statistically significant of the corresponding coefficients at 10\%, 5\% and $1 \%$ level. Standard errors of the corresponding coefficients are reflected in square brackets. 
The results of the quantile regression confirm the previous findings obtained by employing the NARDL estimation approach where the current inflation and REX were found to be the strongest factors contributing to the expected inflation. The REX showed a very strong and statically significant impact on the inflation expectations in ever quantile, suggesting that the ERPT has crucial implications for inflation expectations formation. Inflation and oil price shock also showed a highly significant impact on the Czech inflation expectations suggesting that these crucial factors for inflation expectations in this economy. Similarly, unemployment, money supply and fiscal stance also showed a significant impact on most of the quintiles. This leads us to conclude in the next section.

\section{Conclusion and Policy Implications}

ERPT and its implications for the various aspects of Macroeconomy and price stability are longstanding and much debated issues. I.T. has given this debate a new context and there have been arguments on both sides. There are those who argue that the ERPT has diminished due to I.T. while others have argued that the reverse is the case. In this debate, an underappreciated and unexplored issue is whether inflation expectations act as a channel for the ERPT. Inflation expectations have been considered as a crucial determinant of inflation and hence it seems intuitively reasonable to explore the implications of ERPT for inflation expectations. This study took this task on and analysed the implications of ERPT and other determinants of inflation for inflation expectations. We find that inflation expectations are significantly influenced by the ERPT in the Czech case (a small open I.T. economy). There is also considerable evidence of the asymmetric and non-linear impact of the REX on inflation expectations. Inflation itself was found to have very significant impact on future inflation expectations, which implies that periods of price stability can help to anchor and moor inflation expectations. The other determinants of inflation expectations, including GDP growth, unemployment, oil shocks, money supply, and fiscal discipline also showed considerable impact, though results varied in size and significance and in the long and short-run. We also performed various robustness tests and quantile regression analysis, which provided support to the empirical results and inferences based on a NARDL framework. Our study contributes to debate on I.T. and ERPT through our focus on expectations as a transmission channel. Our study has profound implications for I.T. monetary authorities and policymakers in terms of forward-looking 
policy formulation. In terms of further research, we suggest our framework be extended to other economies including developed and developing countries which have adopted I.T. 


\section{References}

Alpanda, S. Honig, A. (2014), The impact of central bank independence on the performance of inflation targeting regimes, Journal of International Money and Finance, 44, pp. 118-135.

Armantier, O. Topa, G. Klaauw, v.d. W. Zafar, B. (2016), How Do People Revise Their Inflation Expectations? Liberty Street Economics, Federal Reserve Bank of New York.

Angeriz, A. Arestis, P. (2008), Assessing inflation targeting through intervention analysis, Oxford Economic Papers, 60 (2), pp. 293-317.

Artis, M. J. Kontolemis, Z. G. (1998), The European Central Bank and inflation targeting, International Journal of Finance and Economics, 3(1), pp. 27-37.

Atkeson, A. Kehoe, P. J. (2004), Deflation and Depression: Is There and Empirical Link? NBER Working Paper No. w10268.

Balima, W. H. Combes, J. L. Minea, A. (2017) Sovereign debt risk in emerging market economies: Does inflation targeting adoption make any difference? Journal of International Money and Finance, 70 (2), pp. 360-377.

Bernanke, B. S. Laubach, T. Mishkin, F.S. Posen, A. S. (2001), Inflation Targeting: Lessons from the International Experience, Princeton University Press.

Bernanke, B. S. (2003), "Constrained Discretion" and Monetary Policy, Remarks by Governor Ben S. Bernanke before the Money Marketeers of New York University, New York, New York.

Boschia, M. Girardi, A. (2007), Euro area inflation: long-run determinants and short-run dynamics, Applied Financial Economics, 17 (1), pp. 9-24.

Broadbent, B. (2017), Imperial College, London, available at http://www.bankofengland.co.uk/publications/Documents/speeches/2017/speech969.pdf accessed on 1st April 2017.

Canova, F. Gambetti, L. Pappa, E. (2007), The structural dynamics of output growth and inflation: Some international evidence, Economic Journal, 117 (519), pp. C167-C191.

Cerisola, M. Gelos, G. (2009), What drives inflation expectations in Brazil? An empirical analysis, Applied Economics, 41, pp 1215-1227

Corbo, V. Landerretche, O. Schmidt-Hebbel, K. (2001), Assessing inflation targeting after a decade of world experience, International Journal of Finance and Economics, 6 (4), pp. 343-368.

Catao, L.A. Terrones, M. E. (2005) Fiscal deficits and inflation, Journal of Monetary Economics, 52 (3), pp. 529-554

Eichengreen, B. (2002) can emerging markets float? Should they inflation target? Central Bank of Brazil, Working Paper No. 36.

Fischer, S. Ratna S. Vegh, C. (2002), "Modern Hyper- And High Inflations," Journal of Economic Literature, 40(3), 837-880

Forder, J. (2014), A Neglected Inconsistency in Milton Friedman's AREA Presidential Address, Department of Economics Discussion Paper Series, University of Oxford. ISSN 1471-0498. 
Fraga, A. Goldfajn, I. Minella, A. (2003), Inflation Targeting in emerging market economies. In: Gertler, Mark; Kenneth, Rogoff (Orgs.) NBER Macroeconomics annual, 18. MIT Press, pp 365-400.

Frankel, J. (2012), The Death of Inflation Targeting, Project Syndicate, available at https://www.project-syndicate.org/commentary/the-death-of-inflation-targeting accessed on 10th January 2018.

Friedman, M. (1968), The Role of Monetary Policy, American Economic Review, 58, pp 1-17.

Friedman, M. (1970), “The Counter-Revolution in Monetary Theory" by Milton Friedman IEA Occasional Paper, no. 33.

Forbes, Kristin, Hjortsoe, Ida, Nenova, Tsvetelina (2015). "The Shocks Matter: Improving our Estimates of Exchange Rate Pass-Through", Bank of England External MPC Unit Discussion Paper, No. 43.

Forbes, K. (2016). Much Ado About Something Important: How Do Exchange Rate Movements Affect Inflation? The Manchester School, 84 No. S1, pp. 15-41.

Forbes, K. Hjortsoe, I. Nenova, T. (2017), Shocks versus Structure, explaining difference in exchange rate pass-through across countries and time, Bank of England, Discussion Paper N. 50.

Fuhrer, J. C. (2011), The Role of Expectations in U.S. Inflation Dynamics, Working Paper Series (Federal Reserve Bank of Boston), 11 (11), pp. 1-34.

Groshen Schweitzer (1999), Identifying Inflation's Grease and Sand Effects in the Labor Market, NBER Working Paper No. 6061, Chapter in NBER book The Costs and Benefits of Price Stability (1999), Martin Feldstein, editor (p. 273 - 314). University of Chicago Press.

Gali, J. Gertler, M. (1999). "Inflation Dynamics: A Structural Econometric Analysis." Journal of Monetary Economics, 44 (3), pp. 195-222.

Haldane, A. G (2015). How low can you go? Speech given at the Portadown Chamber of Commerce, Northern Ireland, available at http://www.bankofengland.co.uk/publications/Pages/speeches /2015/840.aspx

Haldane, A. (2017), Andy Haldane in conversation, Institute for Government, available at [https://www.instituteforgovernment.org.uk/events/andy-haldane-conversation] accessed on 2nd April 2017.

Hung, H. Thompson, D. (2016) 'Money Supply, Class Power, and Inflation: Monetarism Reassessed', American Sociological Review, 81(3), pp. 447-466.

Ibrahim, M.H. (2015), Oil and food prices in Malaysia: a nonlinear ARDL analysis, 3(2), pp. 3 14.

Jahan, S. (2017), Inflation Targeting: Holding the Line, International Monetary Fund, Finance \& Development, available at http://www.imf.org/external/pubs/ft/fandd/basics/target.htm

Junior, R.P.N. (2007), Inflation targeting and exchange rate pass-through, Economia Aplicada, 11 (2), pp. 189-208.

Lagoa, S. (2017) Determinants of inflation differentials in the euro area: Is the New Keynesian Phillips Curve enough? Journal of Applied Economics, 20 (1), pp 75-103. 
Lanzafame, M. (2016), Inflation targeting and interest rates: a panel time-series approach, Oxford Economic Papers, 68 (2), pp. 484-505.

Lee, W. S. (2011), Comparative case studies of the effects of inflation targeting in emerging economies, Oxford Economic Papers, 63 (2), pp. 375-397.

Lin, H.Y. Chu, H. P. (2013), Are fiscal deficits inflationary? Journal of International Money and Finance, 32, pp. 214-233.

Lu, X. Guo, K. Dong , Z. Wang, X. (2017) Financial development and relationship evolvement among money supply, economic growth and inflation: a comparative study from the U.S. and China, Applied Economics, 49:10, 1032-1045

Marfatia, H. A. (2018), Estimating the New Keynesian Phillips Curve for the UK: evidence from the inflation-indexed bonds market. The B.E. Journal of Macroeconomics. 18(1), pp. $1-18$.

Mehra, Y. P. Herrington, C. (2008), On the Sources of Movements in Inflation Expectations: A Few Insights from a VAR Model, Economic Quarterly, 94 (2) pp. 121-146.

Minea, A. Tapsoba, R. (2014), Does inflation targeting improve fiscal discipline? Journal of International Money and Finance, 40 (2), pp. 185-203.

Minella, A. de Freitas, P.S. Goldfajn, I. Muinhos, M.K (2003), Inflation targeting in Brazil: constructing credibility under exchange rate volatility, Journal of International Money and Finance, 22 (7), pp. 10151040 .

Mishkin, F. S. (2000), Inflation Targeting in Emerging Market Countries, NBER Working Paper No. w7618.

Mishkin, F. Savastano, M. (2001), Monetary policy strategies for Latin America. Journal of Development Economics, 66. pp. 415-444.

Mikek, P. (2004) Inflation targeting and switch of fiscal regime in New Zealand, Applied Economics, 36, pp. 165-72.

Mohanty, M.S. Klau, M. (2001), "What determines inflation in emerging market economies?," BIS Papers chapters, in: Bank for International Settlements (ed.), Modelling aspects of the inflation process and the monetary transmission mechanism in emerging market countries, 8, pp. 1-38 Bank for International Settlements.

Mohanty, D. John, J. (2015), Determinants of inflation in India, Journal of Asian Economics, 36, pp. $86-96$.

Morgan, J. (2009) "The limits of central bank policy: Economic crisis and the challenge of effective solutions." Cambridge Journal of Economics, 33 (4), pp. 581-60.

Morgan, J. and Patomaki, H. (2017) "Contrast explanation in economics: Its context meaning and potential” Cambridge Journal of Economics, 41 (5), pp.1391-1418.

Nasir, M. A. (2017), Zero Lower Bound \& Negative Interest Rates: Choices for the Monetary Policy (February 3, 2017). Available at SSRN: https://ssrn.com/abstract=2881926 or http://dx.doi.org/10.2139/ssrn.2881926

Nasir, M. A. (2017b), Forecasting Inflation under Uncertainty: The Forgotten Dog \& the Frisbee, Available at SSRN: https://ssrn.com/abstract=2968973 or http://dx.doi.org/10.2139/ssrn.2968973 
Nasir, M. A. Simpson, J. (2018), Brexit Associated Sharp Depreciation and Implications for UK's Inflation and Balance of Payments, Journal of Economic Studies, 45 (2), pp.231-246.

Nasir, M. A. Morgan, J. (2018), Pre-Brexit: the EU referendum as an illustration of the effects of uncertainty on the Sterling exchange rate, Journal of Economics Studies, 45 (5), 910-921.

Nasir, M. A. Vo, V.X (2018), A Quarter Century of Inflation Targeting \& Exchange Rate PassThrough: Evidence from the First Three Movers, Available at SSRN: https://ssrn.com/abstract=3130082 or http://dx.doi.org/10.2139/ssrn.3130082

Nasir, M.A. Morgan, J. (2018) The unit root problem: Affinities between ergodicity and stationarity, its practical contradictions for central bank policy, and some consideration of alternatives, Journal of Post Keynesian Economics, 41:3, 339-363

Nasir, M. A. Naidoo, L. Shahbaz, M. Amoo, N. (2018), Implications of oil prices shocks for the major emerging economies: A comparative analysis of BRICS, Energy Economics, 76:76-88.

Nasir, M. A. Balsalobre-Lorente, D. Huynh, T.L.D. (2020), Anchoring inflation expectations in the face of oil shocks \& in the proximity of ZLB: A tale of two targeters, Energy Economics, 86, https://doi.org/10.1016/j.eneco.2020.104662.

Nasir, M.A. Huynh, T.L.D. Yarovaya, L. (2020b), Inflation targeting \& implications of oil shocks for inflation expectations in oil-importing and exporting economies: Evidence from three Nordic Kingdoms, 4th Vietnam Symposium in Banking and Finance, Hanoi, Vietnam.

Norkute, M. (2015), Can the sectoral New Keynesian Phillips curve explain inflation dynamics in the Euro Area? Empirical Economics, 49:1191-1216

Obstfeld, M. (2014), Never Say Never: Commentary on a Policymaker's Reflections, IMF Econ Review (2014) 62: 656.

Pesaran M.H. Shin Y. (1999), An autoregressive distributed lag modelling approach to cointegration analysis. In: Storm S (ed) Econometrics and Economic Theory in the 20th Century: The Ragnar Frisch Centennial Symposium, Chapter 11. Cambridge University Press, Cambridge.

Pesaran MH, Shin Y, Smith RJ (2001) Bounds testing approaches to the analysis of level relationship. Journal of Applied Econometrics, 16:289-326.

Phelps, E. S. (1967), Phillips Curves, Expectation of Inflation and Optimal Unemployment Over time, Economica, 34, pp. 254-281.

Posen, A. (2011), The Soft Tyranny of Inflation Expectations The Soft Tyranny of Inflation Expectations. International Finance, 14 (3). pp. 541-566.

Roger, S. (2010), “Inflation Targeting Turns 20,” Finance \& Development, 47 (1), pp.46-49.

Sargent, T. J. Wallace, M. (1981), Some unpleasant monetarist arithmetic Federal Reserve Bank of Minneapolis Quarterly Review, 5 (3), pp. 1-17.

Sargent, T. and Wallace, N. (1986) Some unpleasant monetarist arithmetic, in, Rational Expectations and Inflation, Harper \& Row, New York.

Schmidt-Hebbel, K. Werner, A. (2002) inflation targeting in Brazil, Chile and Mexico: performance, credibility and the exchange rate. Central Bank of Chile, Working Paper No 171. 
Shin Y, Yu B, Greenwood-Nimmo M (2011) Modelling Asymmetric Cointegration and Dynamic Multiplier in a Nonlinear ARDL Framework, Mimeo.

Su, C. Fan, J. Chang, H. Li, X. (2016), Is there Causal Relationship between Money Supply Growth and Inflation in China? Evidence from Quantity Theory of Money. Review of Dev Econ, 20: 702-719.

Ouattara, B. (2004). Modelling the long run determinants of private investment in Senegal (No. 04/05). Credit Research Paper.

Tobin, J. (1972). Inflation and Unemployment. American Economic Review 62 (March): pp. 1-18.

Ueda, K. (2010), Determinants of households' inflation expectations in Japan and the United States, Journal of the Japanese \& International Economies, 24 (4), pp. 503-518.

Unsal, D.F. Osorio, C. (2013), Inflation dynamics in Asia: Causes changes and spillovers from China Journal of Asian Economics, 24, pp. 26-40

Williams, J.C. (2014), Inflation Targeting and the Global Financial Crisis: Successes and Challenges, Conference on Fourteen Years of Inflation Targeting in South Africa and the Challenge of a Changing Mandate.

Yigit, T. M. (2010) Inflation targeting: An indirect approach to assess the direct impact, Journal of International Money and Finance, 29 (7), pp. 1357-1368. 